\title{
Lotman in an interdisciplinary context: A symposium held at the University of Michigan
}

\author{
Andreas Schönle ${ }^{l}$
}

A symposium The Works of Iurii Lotman in an Interdisciplinary Context: Impact and Applicability has been held at the University of Michigan, USA, on October 29, 1999.

The premise of the conference was to bring together scholars from a variety of disciplines who have used Lotman in their work and who could reflect on the ways in which Lotman enriches (or, sometimes, fails to enrich) their discipline, as currently practiced in the United States. The conference organizers, Jeremy Shine and the author of these lines, deliberately sought to invite scholars who had had no personal contact with Lotman, be it as colleagues or students. The emphasis was placed on the late works of Lotman, such as Universe of the Mind and Culture and Explosion, those in which Lotman attempts to go beyond the de Saussurian foundations of his semiotics. The implicit agenda of the conference, ultimately, was to reclaim some parts of Lotman's works that had not been sufficiently heeded in American academia and that could contribute to a kind of mapping out of the field of post-structuralist Cultural Studies and its various sub-branches.

In a paper called "Bipolar disorders: The semiotics of asymmetry in Lotman, Bakhtin, and Levinas", Amy Mandelker proposed a reading of Lotman's Culture and Explosion in the context of theories of otherness inspired by neo-Kantianism and twentieth-century Jewish philosophy (Franz Rosenzweig, Walter Benjamin, and Emmanuel Levinas). Mandelker drew a parallel between Lotman's concept of explosion and Benjamin's messianic idea of the "angel of history" and interpreted the notion of self-giving (vruchenie sebya) as a reformulation of Kant's categorical imperative and as a reference to the Jewish practice of estrangement exemplified in Levinas's

1 Author's address: Andreas Schönle, Department of Slavic Languages and Literatures, MLB 3040, The University of Michigan, Ann Arbor, MI 48109-1275, USA; e-mail: aschonle@umich.edu. 
emphasis on the self-inflicted violence involved in the response to the suffering of the other. Altogether, Mandelker demonstrated how Jewish metaphysics were inscribed into Lotman's secular post-structuralist semiotics.

In "Lotman, film theory and verse theory", Herbert Eagle analyzed the cross-fertilization between film and verse theory in Lotman's works. Verse theory, as adapted from Iurii Tynianov, provided Lotman with the fruitful concept of double asymmetric encoding, which, when applied to film, yielded the notion of an interweaving of conventional and iconic codes as the underlying principle of cinema. Eagle showed how Lotman's key concepts of indeterminacy, asymmetry, and, ultimately, creativity, emerged out of his analysis of cinema.

Andrei Zorin approached Lotman from the vantage point of the history of mentality and ideology. "Lotman's Karamzin myth and the mentality of the intelligentsia in the late Soviet period" traced how Lotman contributed to elaborate the ethos of late Soviet intelligentsia, which sought a way out of an unbearable alternative between risky dissident activity and self-compromising attempts to bring about reforms within the Communist party. The intelligentsia found a third way in a kind of stoic everyday work ethic and sought to identify in Russian history analogies for its current position. Zorin demonstrated that Lotman projected his behavorial stance onto Karamzin, turning the historiographer into a kind of mirror of, and paradigm for, his own existential choices, which led him to misread key elements of his historiographic writings.

Andreas Schönle analyzed the typological parallels between Lotman's and Stephen Greenblatt's cultural poetics. Both writers attempt to delineate a theory of the relationship between culture and the social sphere that does not fold the cultural into the social and remains sensitive to the intrinsic vigor of culture, to individual agency and creativity. "Social power and individual agency: The self in Greenblatt and Lotman" articulates the differences between Lotman's biochemical and Greenblatt's economic metaphors of cultural exchange. Both authors analyze the homogenizing strategies of power, but Green-blatt's sense for diffuse, plural sources of power contrasts with Lotman's idea of a centralized, unique source. These notions of power determine varying ideas of selfhood. If for Greenblatt cultural life is fluid and complex enough to enable the self to negotiate some degree of autonomy, if only an illusory one, for Lotman, the further withdrawn from the center of culture, the freer one is.

A series of papers addressed Lotman's relevance for historians. In "Lotman for historians: Reading the potentials" James von Geldern pointed to several gaps in Lotman's approach to culture, notably his canon-centered neglect of popular culture, of gender issues, and of the experience of certain social classes. On the example of the urban romance, Geldern tried to illustrate how the opposition between high and popular culture would complicate Lotman's main articulation between center and periphery. Kristi Groberg used Lotman's ideas of the semiosphere to analyze the case of a 
multi-lingual ethnic community. In "Lotman as key to understanding RussianJewish trilingualism" she discussed the applicability of Lotman's semiotics to ethnic studies.

Finally, Kathryn Babayan was primarily concerned with conceptualizing historical change. She began by observing that theorists such as Lévi-Strauss, Geertz, Barthes, Bourdieu, and Foucault have not developed a framework that could explicate the dynamics of historical change. Lotman's binary model of cultural change, enhanced by the theory of the semiosphere as a site of interaction between multiple languages, offers a way to conceptualize such a process, without loosing a sense of complexity and heterogeneity. Her paper analyzed a case study of conflict in sixteenth-century Iran between Islamic culture and the Nuqtavi messianic movement, which sought a return to Zoroastrianism and championed the Persian past. Lotman's framework enabled her to explain the astonishing endurance of cultural memory in Iran and the syncretic phenomenon of change amidst underlying continuities.

The last group of papers was devoted to attempts to model culture in cybernetics, anthropology, and political theory. To set the stage, Kelly Miller's 'Defining the 'thinking brain': Lotman's response to Turing" offered a reading of Lotman's Universe of the Mind as a manifesto on artificial intelligence. She placed Lotman's proposal to view culture as collective intellect and to model artificial intelligence thereafter in the context of polemics on the proper modeling of intelligence. Referring at once to analytical philosophy, cybernetics, and semiotics, she analyzed both the advantages and pitfalls of his paradigm, which essentially finds in artistic texts and their asymmetric bi-polar mechanism an externalized isomorph of intelligence. In "Lotman and absent Lotman in ethnography in the U.S. and U.S.S.R." Alaina Lemon compiled references to Lotman in several major American and Soviet ethnographic journals, noting the scarcity of such references, and discussing the reasons for such apparent neglect of Lotman's paradigm in ethnographic scholarship.

From the vantage point of linguistic anthropology, Bruce Mannheim made the case that Lotman's semiotics enabled an understanding of post-colonial culture more adequate than that proposed by neo-marxist approaches. Analyzing a Quechua ritual text, "Lotman, culture, and metalanguage" illustrated how the Indians embedded Christian hymnology into their religious practices and how enigmatic metalinguistic phrases served as keys to submerged pagan codes that endured despite the dominance of Catholic colonial discourse. In so doing, Mannheim demonstrated the existence of a cultural metalanguage despite the absence of explicit metalinguistic lexical registers in the Quechua language.

Finally, Michael Urban analyzed the ways in which political rhetoric in post-Soviet Russia seeks to create political communities by using patently non-sensical discourse to strengthen the identity of a political group. Urban demonstrated how binary oppositions, autocommunication, and non-referential discourse reinforce one another in the production of a discourse aimed 
more at creating internal cohesion within a group than communicating any information to an outsider. The paper thus evoked the advantages to be derived from Lotman's analysis of the semiosphere over positivistic political theory, which takes at face value the denotative value of political discourse, and over Habermas' notion of "distorted communication", which mistakes self-directed discourse for communication with the other. The paper thus developed a theory of political culture that refines the simple 'us-them' dichotomy assumed by theorists of inter-group relations.

A lively round-table discussion followed the presentation of these papers. The discussion centered first on Lotman's concept of power, which was contrasted with that by Gramsci and Foucault. Two issues seemed of paramount importance, the correlation between semiotic power and raw disciplinary practices that Lotman fails to address, partly, to be sure, because in the context of Soviet repression, state violence was too conspicuous to need elaboration; and the question of whether power is wedded to unity or not. The ethical implications that emerge from Lotman's works were noted with surprise. Indeed, echoes between the papers by Mandelker, Schönle, and Zorin suggest the degree to which Lotman's stoic existential stance shines through his semiotics and history of culture. Lotman's concept of the semiosphere was again taken up. Participants debated the extent to which the biological metaphors used by Lotman implied an essentialism. Most agreed that the organicist paradigm serves not to essentialize discourse, but to restore to it a sense of the unceasing life, the continuous metabolic exchanges discourses undergo when they are thrown into the world. The round-table also revisited the important idea that Lotman offers a means to conceptualize historical change distinct from, say, Hegelian dialectics or Foucaultian archeological shifts.

Given its broad interdisciplinary basis, the cohesion of the conference was so remarkable that it prompted the organizers to prepare a collective volume based on a selection of papers presented at the conference and augmented by articles solicited specifically for this volume. Provisionally entitled Lotman and Cultural Studies: Encounters and Extensions, this collection is now almost ready to be submitted to a publisher. It engages a broad range of theories and disciplines, including literary criticism, the history of mentalities, the history of philosophy and religions, cultural theory, cinema, political science, anthropology, and the history and theory of everyday life. Its contributors hope that it has the potential of making a definite impact on a variety of fields in the humanities and social sciences, extending thereby Lotman's efforts to break disciplinary boundaries. 